\title{
The Combination of Dribbling and Shooting Training Model Based on Speed and Agility in Football
}

\author{
Yulianto Dwi Saputro \\ Physical Education, Health, and \\ Recreation \\ IKIP Budi Utomo \\ Malang, Indonesia \\ yulianto@budiutomomalang.ac.id
}

\author{
Sudarsono \\ Physical Education, Health, and \\ Recreation \\ IKIP Budi Utomo \\ Malang, Indonesia \\ sudarsono@budiutomomalang.ac.id
}

\author{
Luthfie Lufthansa \\ Physical Education, Health, and \\ Recreation \\ IKIP Budi Utomo \\ Malang, Indonesia \\ luthfie@budiutomomalang.ac.id
}

\begin{abstract}
- this study used the research and development method to develop a new product which is a dribbling and shooting combination training models in football games with speed and agility base for students at Unibraw 82 Football School of Malang, as this is also the aim of the study. The selection of this model was based on the product which is developed using learning through media development which has the following steps: (1) determining ideas, by collecting information as the basis for thinking in order to créate a concept; (2) writing media script product containing the sketches of shooting practice models; (3) product evaluation; (4) product revision I; (5) prototype product, which involves giving the model of shooting practice to a small or large group;
\end{abstract} (6) prototype trial; (7) product revision II; and (8) reproduction. The subjects for the study were selected by random sampling from experts and students of Unibraw 82 Football School of Malang of which 8 students were taken as trial for small group and $\mathbf{1 5}$ students taken as trial for large group. Information gathered from the questionnaires given to them were subjected to analysis using the descriptive quantitative with percentage. The dribbling and shooting combination training models in improving speed and agility in football game for students at Unibraw 82 Football School of Malang were described as follows: (1) cross dribbling and straight shooting training model of the try out small group was $87.5 \%$ while that of the large group was $93.3 \%$; (2) straight dribbling and straight shooting training model of the try out small group was $75 \%$ while that of the large group was $80 \%$; (3) zig-zag dribbling and zig-zag without ball training model of the try out small group brought $62.5 \%$ while that of the large group gave $73.3 \%$; (4) wall-pass shooting training model of the try-out small group was $80 \%$ while that of the large group was $86.6 \%$; (5) spin shooting training model of the try-out small group was $62.5 \%$ while that of the large group was $80.6 \%$; (6) individual dribbling and shooting training model of the try-out small group was $75 \%$ while that of the large group was $86.6 \%$; (7) single shooting training model of the try-out small group was $75 \%$ while that of the large group was $86.6 \%$; (8) stop-ball passing and shooting training model of the try-out small group was $87.5 \%$ while that of the large group was $93.3 \%$; (9) sideways dribbling training model and shooting of the try out small group was $87.5 \%$ while that of the large group was 93.3\%; and (10) sideways dribbling and middle shooting training model of the try-out small group was $87.5 \%$ while that of the large group was $93.3 \%$. In general, the implementation of these training models are feasible for the students of Unibraw 82 Football School of Malang. And the application of these ten training models will allow the students overcome saturation and add some variations to their trainings.

Keywords—combination, training model, football

\section{INTRODUCTION}

It is fact that football is one of the most popular sports. And sport games, in general, can be a mixture of an individual work and that of a team as a whole in such a way that everybody cooperate and work towards achieving a desired result. Unlike other sports, football is a simple game [1] Basically, it involves moving the ball beyond the opposing goal line without using the hands or arms [2]. Just like every other games, there are basic techniques in football game that every player must know, these include: shooting, controlling, dribbling, fake motion, heading, tackling, and throw-in. It is a must for football players to master all these basic techniques and they can do this during their normal practice, however, every player needs some level of discipline in order to get the desired result.

Shooting technique involves moving the ball on the field of play with some power therby creating goals opportunities. A good shooting is possible when the player having the ball in his possession creates space between him and the opposing players in order to hit the ball with some power towards the goal. To be able to control ball, a player needs to train repeatedly in a systematic manner which imparts on his shooting skill because to shoot well, a player needs to first control the ball and then has the knowledge of right timing when to hit it.

Getting the desired results in football does not only require the physical abilities, individual skills and tactics or mental competence of a player, the right coaching foundation is also of great importance. A coach should have an indepth knowledge of the game and know when to conduct trainings in order to improve the team in terms of tactics and ability since football is a game that requires some tactical skills and strategies, apart from the physical ability of individual players in the team such that the team can perform at an optimal level. And a good trainer should organise different exercise or training programs for children, adolescents and adults based on the developmetal needs of the team.

According to Suharno [3], exercise is a conscious process every athlete needs to subject himself to in order to achieve high level performance physically, technically, tactically and mentally. And relating this to football games, especially when it ccomes to practising shooting skills, the above theory must be fully understood so as to get the desired results which is evident in the players ability while playing matches.

A study conducted by [4], explains that exercise aims: (1) to achieve and improve multilateral physical development; (2) 
to develop special physical characteristics based on the needs of the sports in question; (3) to refine the team; (4) to improve the strategies and techniques required by the team in different circumstances; (5) to improve the team's personality; (6) to ensure that the individuals and the team as a whole is always prepared; (7) to maintain the health condition of the athletes; (8) to prevent injury; and (9) to improve their theoretical knowledge. And shooting practice as an exercise aims at sharpening the ability of players in terms of kicking the ball with a specific direction in mind.. Additionally, a good exercise is an exercise that looks like or resembles a real game [5]. Therefore, a good coach must do everything in creating such an environment so that the team can achieve their desired goals in real matches.

The results from the preliminary study carried out at Unibraw 82 Soccer School of Malang showed that an exercise model has not been implemented in any way, thereby affecting the effectiveness and the efficiency of the team. They followed the conventional way in doing their trainings and while having the dribbling and shooting sessions, there was no input from a coach most of the times. With that, there was no special trainings on the different shooting or dribbling strategies thereby making it difficult for them to win matches, and as such, no improvement in the individual performance and that of the team as a whole. This simply showed that the aim of football games was not achieved. In view of the situation presented above, there were researchers who suggested the need to develop a proper model for dribbling and shooting combined, based on the speed and agility of the students at Unibraw 82 Football School (SSB) of Malang.

The problem on ground, in line with this study, is the need to develop some dribbling and shooting combination models in a football game based on the speed and agility of the students at Unibraw 82 Football School of Malang, in which its abscence has not been helpful to the individual players and the team as a whole. Then the significances of the study are as follows; (1) football players can improve their dribbling and shooting skills in football; (2) coaches can use this study as a reference material for implementing dribbling and shooting exercises that also accommodate speed and agility training; and (3) researchers can develop the study better so that it can be used as a reference in related studies.

\section{METHOD}

This study used Research and Development (R \& D) method and it aims at producing a new product which is the combination of dribbling and shooting exercise model in a football game based on speed and agility. In this study, the development model used was the instructional development model of [6]. This model was selected based on the suitability of the developed products with the model used, in other words, Sadiman development model is a model of learning through media development.

The design of instructional development from Sadiman has the following steps: (1) the determination of ideas, by collecting information as the basis for thinking in order to create a concept; (2) writing a media script (product) consisting of sketches of shooting practice models; (3) product evaluation; (4) revision of product I; (5) prototype product, which involves giving the model of shooting practice to a small group or a large group; (6) prototype trial, which involves testing the result of product revision I. And the trial was done by the players at Unibraw 82 Football School of Malang with the expectation that from the trial, data collected will be used as an improvement in producing the final product of dribbling and shooting combination model; (7) revision of product II, which involves revising the players of Unibraw 82 Football School of Malang as subjects; (8) reproduction, this has to do with the improvement of the final product developed.

The data collection technique used in this research was questionnaire technique which was distributed to experts in football game and students of Unibraw 82 Football School (SSB) of Malang. According to [7], questionnaire is a set of written questions used to obtain information from respondents about things personal to them and some of the things they know. And the set of questions for experts is different from those for the school players. The data analysis technique used in this study was descriptive quantitative analysis with percentage. The formula is as follows:

$\mathrm{P}=\frac{\mathrm{F}}{\mathrm{N}} \mathrm{x} 100 \%$

where,

$\mathrm{P}=$ Percentage searched

$\mathrm{F}=$ Frequency of subjects who choose the alternatives

$\mathrm{N}=$ Total number of subjects

(Sudjana, 1990: 131)

This was supported by Guiford opinion in [8], which helps in decisión-making process and in clarifying percentage analysis results.

Table 1. Classification of Shooting and Dribbling Combination at Unibraw 82 SSB of Malang

\begin{tabular}{|c|c|c|}
\hline Percentage & Classification & Mean \\
\hline $0-20.0 \%$ & Not Good & Dumped \\
\hline $20.1-40.0 \%$ & Not Good & Fixed \\
\hline $40.1-70.0 \%$ & Enough & Used (Conditional) \\
\hline $70.1-90.0 \%$ & Good & Used \\
\hline $90.1-100 \%$ & Very Good & Used \\
\hline
\end{tabular}

\section{RESUlT AND DISCUSSION}

This research produced dribbling and shooting combination exercise models in improving the speed and agility of students at Unibraw 82 SSB of Malang as follows. 
1. Cross Dribbling and Straight Shooting Training Model Sprint

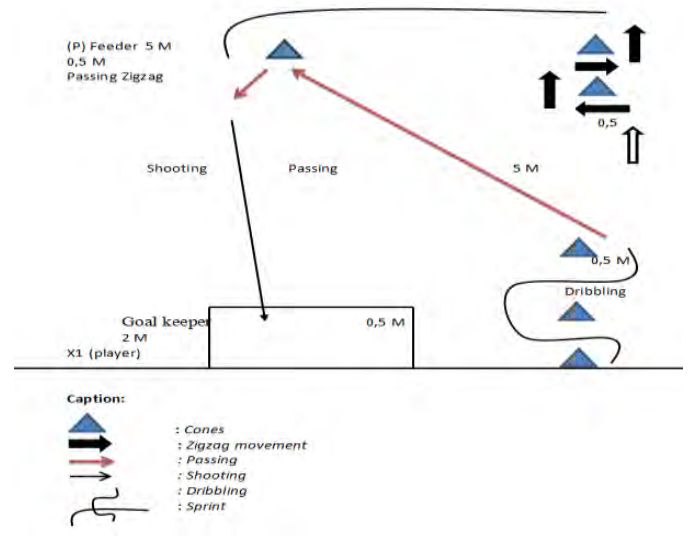

In the expert validation and field trials on the cross dribbling and straight shooting training model, the small group was $87.5 \%$ while the large group was $93.3 \%$.

Performance instruction of the first training model:

Player X1 performs a zigzag dribbling before passing the ball to the Feeder P, then Player X1 zigzags followed by sprinting around $\mathrm{P}$ before finally shooting the ball towards the goal.

\section{Straight Dribbling and Straight Shooting Training Model}

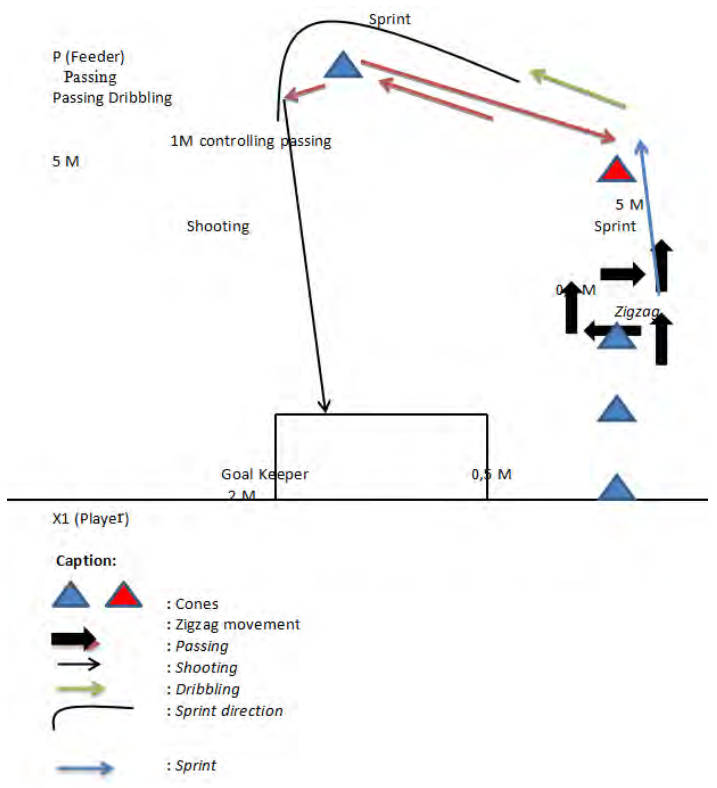

In the expert validation and field trials on straight dribbling and straight shooting training model, the small group was $75 \%$ and the large group was $80 \%$.

Performance instruction of the second training model:

Player X1 performs a zigzag movement, then sprints to the right side of the red cone, the Feeder $\mathrm{P}$ passes the ball to X1 near the red cone, then $\mathrm{X} 1$ controls the ball followed by dribbling and then passes to $\mathrm{P}, \mathrm{X} 1$ will also sprint and turn around $\mathrm{P}$ while $\mathrm{P}$ performs a slow passing of the ball to the right side and then $\mathrm{X} 1$ finally shoots the ball towards the goal.
3. Zigzag Dribbling and Zigzag without ball Training Model

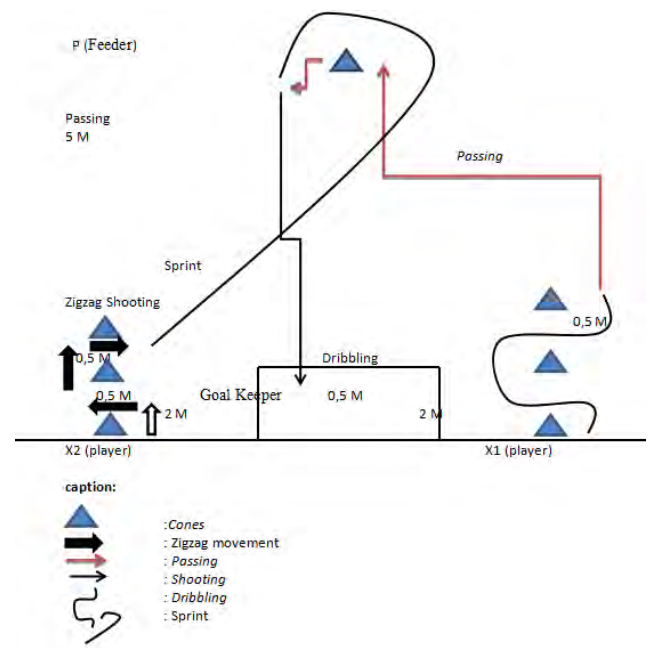

In the expert validation and field trials on zig-zag dribbling and zigzag without ball training model, the smallgroup was $62.5 \%$ while the large group was $73.3 \%$.

Performance instruction of the third training model:

Player X1 performs dribbling together with Player X2 that will do a zigzag, after the dribbling of Player X1, he will cross pass the ball to the Feeder $\mathrm{P}$ and after the zigzag of Player X2, he will sprint and turn around the Feeder P, then $\mathrm{P}$ will pass the ball to the right side and $\mathrm{X} 2$ shoots the ball to the goal direction, Player X1 then changes position with Player X2, and X2 as well takes the position of X1 while they repeat the whole process.

\section{Wall Pass Shooting Training Model}

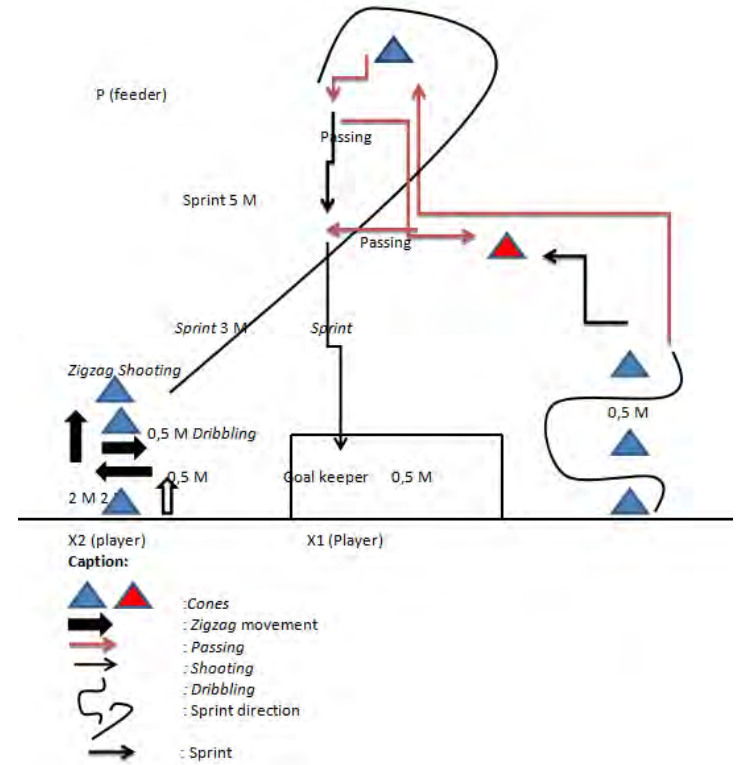

In the expert validation and field trials on the wall pass shooting training model, the small group trial was $80 \%$ while the large group was $86.6 \%$.

Performance instruction of the fourth training model: 
Player X1 performs a zigzag dribbling as well as Player $\mathrm{X} 2$, Player X1 cross passes the ball to Feeder P after doing the dribbling and then sprints towards the red cones so as to receive a feedback from Player X2 and also feeds the sideways player, $\mathrm{X} 2$ sprints and turn around $\mathrm{P}$ after the zigzag dribbling, then $\mathrm{P}$ passes the ball to the right, $\mathrm{X} 2$ then passes the ball to $\mathrm{X} 1$, which in turn feeds the sideways player before X2 finally shoots the ball towards the goal.

\section{Spinning Shooting Training Model}

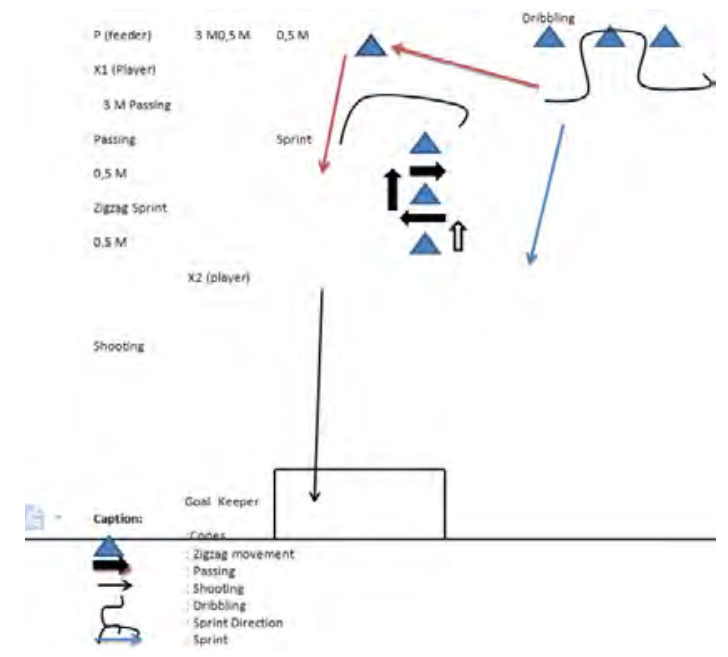

In the expert validation and field trials on the wall pass shooting training model, the small group trial was $80 \%$ while the large group was $86.6 \%$.

Performance instruction of the fifth training model:

Player X1 performs a zigzag dribbling together with Player X2, Player X1 cross passes the ball to Feeder P and then sprints to the red cones to receive feedback from X2, X1 feeds the sideways player while X2 after zigzag sprints and turn around $\mathrm{P}$, then $\mathrm{P}$ passes the ball to the right, $\mathrm{X} 2$ then passes the ball to $\mathrm{X} 1$ which in turn feeds the sideways player and X2 finally shoots towards the goal.

\section{Individual Dribbling and Shooting Training Model}

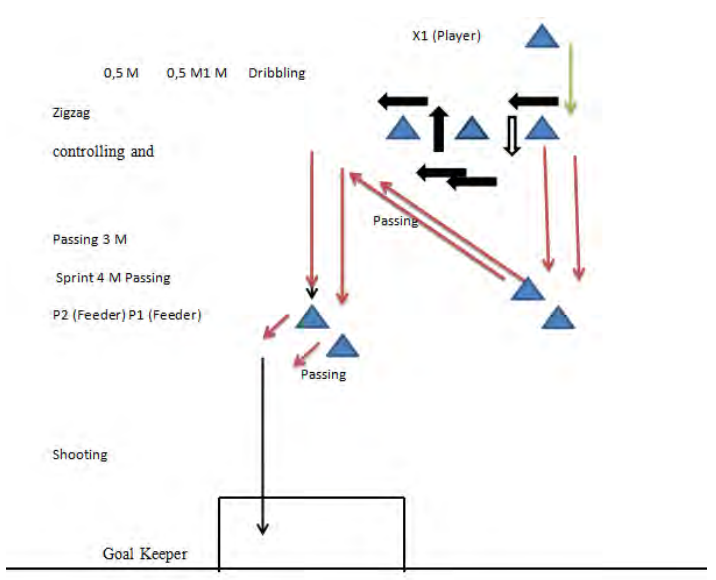

In the expert validation and field trials on individual dribbling and shooting practice model, the small group was $75 \%$ while the large group was $86.6 \%$.

Performance instruction of the sixth training model:

Player X1 performs a zigzag dribbling and then passes the ball to Feeder P1, P1 passes to X1 who in turn controls the ball and passes it to Feeder P2, while P2 passes to the right before X1 sprints and finally shoot towards the direction of the goal.

\section{Individual Player Shooting Training Model}
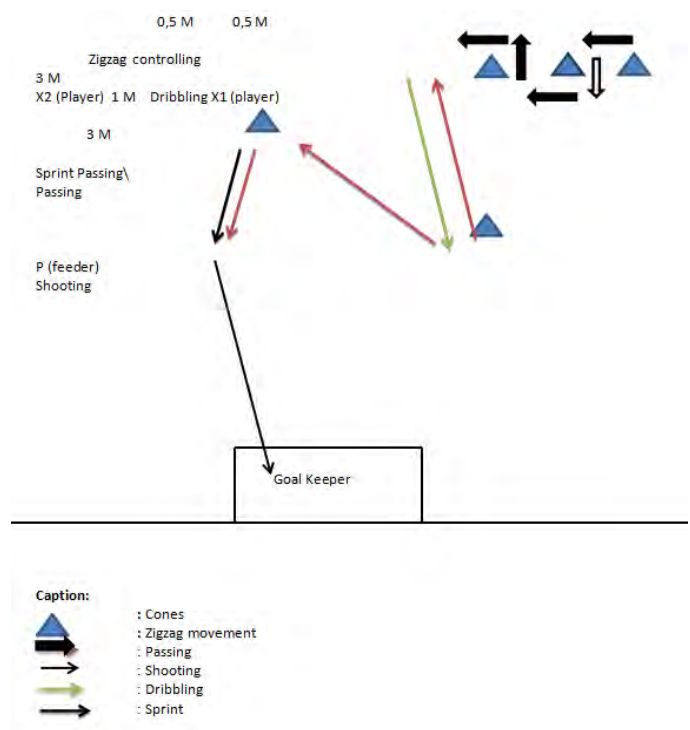

In the expert validation and field trials on individual player shooting practice model, the small group was $75 \%$ while the large group was $86.6 \%$.

Performance instruction of the seventh training model:

Player X1 performs a zigzag movement until he gets to the last cone after which the Feeder $\mathrm{P}$ passes the ball to him. $\mathrm{X} 1$ then dribbles and passes the ball to $\mathrm{P}$ and then passes it to Player X2 who will kick the ball back and then sprint before shooting the ball towards the goal. 
8. Stopped Ball Passing and Shooting Training Model
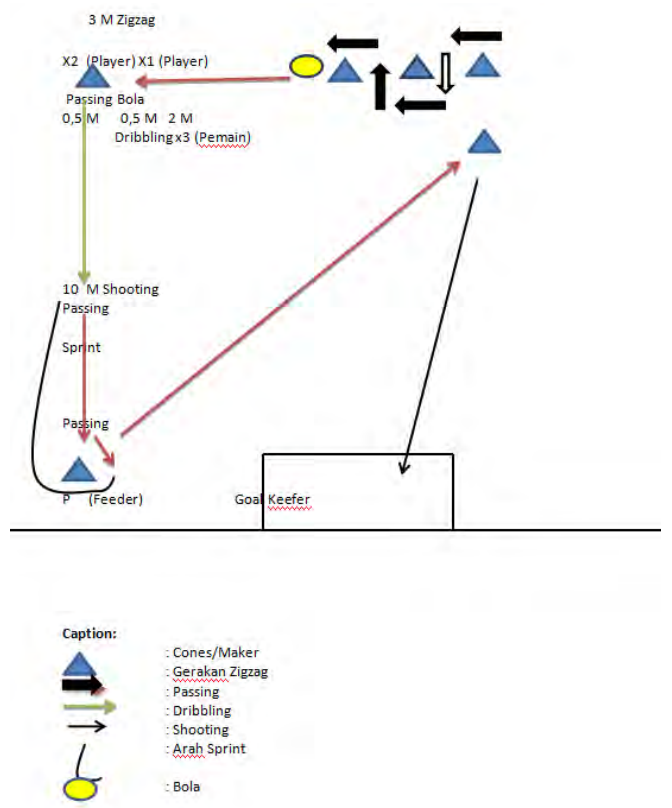

In the expert validation and field trials on stopped ball passing and shooting practice model, the small group was $87.5 \%$ while the large group was $93.3 \%$.

Implementation instruction of the eighth training model:

Player X1 performs a zigzag movement with the ball until he gets to the last cone and then passes it to Player X2 after which X2 controls the ball, dribbles and then passes it to Feeder $\mathrm{P}$. Then $\mathrm{X} 2$ performs sprint and turns around $\mathrm{P}$ after which $\mathrm{P}$ feeds the ball towards the right side. X2 then passes the ball to Player 3 who will shoot the ball towards the goal.

\section{Dribbling from the Sides and Shooting Training Model}

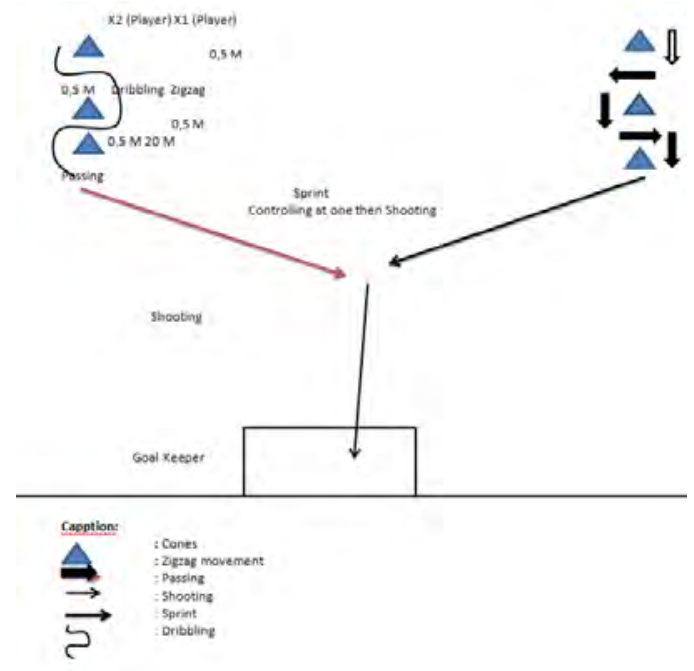

In the expert validation and field trials on dribbling from the sides and shooting practice model, the small group was $87.5 \%$ while the large group was $93.3 \%$.
Implementation instruction of the eighth training model:

Player X1 performs a zigzag movement with the ball until he gets to the last cone as well as Player X2, and then passes the ball to $\mathrm{X} 2$. He sprints, controls the ball on the side line and then shoots the ball towards the goal.

\section{Dribbling from Sides and Shooting from Middle Training Model}

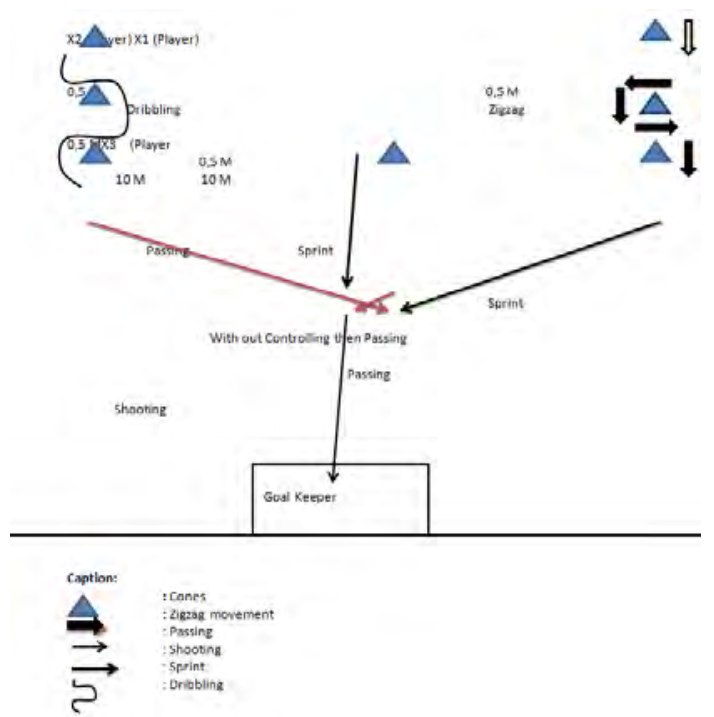

In the expert validation and field trials on the dribbling from the sides and shooting from the middle training model, the small group was $87.5 \%$ while the large group was $93.3 \%$.

Performance instruction of the tenth training model:

Player X1 performs a zigzag dribbling until he gets to the last cone and Player X2 does likewise. . X2 then cross passes the ball forward while X1 sprints to catch the ball. Without controlling, X1 passes the ball and then Player X3 sprints and shoots the ball towards the goal.

Observing the models as highlighted above, the following conclusions can be drawn as regards its effects on the speed and agility of the football team: (1) cross dribbling and straight shooting training model validated by experts and field trials in small group was $87.5 \%$ while in the large group was $93.3 \%$; (2) straight dribbling and straight shooting training model validated by expert and field trials in small group was $75 \%$ while in the large group was $80 \%$; (3) zigzag dribbling and zig-zag dribbling without the ball training model validated by experts and field trials in small group was $62.5 \%$ while in the large group is $73.3 \%$; (4) wall pass shooting training model validated by experts and field trials in small group was $80 \%$ while in the large group was $86.6 \%$; (5) spinning shooting training model validated by experts and field trials in small group was $62.5 \%$ while in the large group was $80.6 \%$; (6) individual dribbling and shooting training model validated by experts and field trials in small group was $75 \%$ while in the large group was $86.6 \%$; (7) individual shooting player training model validated by experts and field trials in small group was $75 \%$ while in the 
large group was $86.6 \%$; (8) stopped ball passing and shooting training model validated by experts and field trials in small group was $87.5 \%$ while large group is $93.3 \%$; (9) dribbling the sides and shooting training model validated by experts and field trials in small group was $87.5 \%$ while in large group was $93.3 \%$; and (10) dribbling from the sides and shooting from the middle training model validated by experts and field trials in small group was $87.5 \%$ while in the large group was $93.3 \%$. In general, the implementation of these training models are feasible for the students of Unibraw 82 Football School of Malang.

These models above are similar with one of the most fundamental techniques in football game which is dribbling. There is a need for every footbaler to master this technique [9]. Using this technique makes football game lively especially when combined with other techniques like passing or shooting. And basically, dribbling is the ability to take the ball past an opponent while still being in control of the ball, whether by using a series of simple taps or a skillful move around an opponent in a football game. It has an element of art in it because a touches the ball with his feet and is able to change direction and speed while running with the ball [5].

There are various forms of dribbling techniques and these include the following:: (1) dribbling with the outside of the foot; (2) dribbling with the inside of the foot; and (3) dribbling with the instep of the foot. And according to [10], in his book titled, "Football Basics" gave the following explanations on these three forms mentioned above: (1) Dribbling using the inside of the foot involves touching the ball in such a way that the ball rests on the inside of the foot and the position of the foot is perpendicular to the ball. The ball is kicked slowly so as to maintain its possession and then focus on shooting it at the center for easy control. Also in this form of technique, the direction of the ball is always towards the right or left side of the body. (2) Dribbling using the outside of the foot involves touching the ball such that it rests on the foot. This ball controlling skill is used when the player controlling the ball is running and pushing the ball so that he can direct it and makes it remain outside the foot. This form of technique is the same with dribbling using the inside of the foot in that the ball is always directed towards the right or left of the body. (3) Dribbling using the instep of the foot is different from the two mentioned above in the sense that the ball is always directed straight ahead. The instep of the foot is a common term used for that part of the foot where the shoelace is located and the ball and the feet meet in this section. But beginners always make a mistake in that they make use of the tip of their toes while trying to this.

The success of a player in any football game is to score goals and this depends on several factors among which is the ability to shoot the ball towards the opposing goal using both feet with precisión. A player's technical ability is also of great importance when it comes to taking goal scoring decisions on the field of play. And as a matter of fact, a player should be able to practice and perfect his shooting technique and do so in a situation where conditions similar to those of a real game are provided. Aside that, a player should be able to shoot the ball even when it is rolling, bouncing or coming from air. These are avrious conditions that should be mastered by players.

According to [5], there are things to be taken into consideration during shooting technique, these include: (1) Preparing the ball with the side of the foot used for shooting; (2) Adjusting the direction of the footsteps against the ball and then setting the foot as a pedestal a few inches beside the ball; (3) Directing the hips to the target while swinging the foot;(4) Bending the foot forward so that the foot touches the ball while shooting. While doing this, make sure that your ankle is locked so that your feet do not twist while kicking the ball; (5) continuously swinging your foot in a forward motion without stopping in order to optimize your shooting power.

In addition, there are situations whereby a player can easily shoot without requiring much skill but in other situations, a player needs to go beyond the basic techniques in order to shoot well. For example, when the player gets the ball while it is rolling bouncing or falling from the air, he needs skills to control it before he can make any attempt of shooting. Some of these skills needed in such situation include Instep Drive, Full Volley, Half Volley, Side Volley and Swerving.

While having trainings using the basic techniques above, three things should be in mind: low accuracy, strength, and shot trajectory. These should be the main targets but if a player consistently fails to achieve any of these these goals, then the chances are that such player will have a Little or zero chances of scoring goals [11].

It should be noted that research and development method is carried out by some scientific rules, therefore, every stage of this research work was done carefully following those rules. For this reason, it expected to get a good product that is really needed in the field of sport. [12] in his work, stated that research and development method is a scientific study method that examines a theory, model, concept, or principle and uses the results of such study to develop a new product. It is not a research method used for testing theories but are produced as a result of it can be tested and revised so as to obtain satisfactory results.

\section{CONCLUSION AND SugGestions}

On the basis of the data received through expert validations, field trials and the observations during the research and development method undertaken, the study came up with some modifications to the product. These revisions are as follows:

1. Shooting and dribbling training model is arranged as simple, medium, and difficult.

2. Each training model should consider the distance among the players, opponents, and the goal.

3. Each training model should consider the age category of the players, in this case, the Unibraw'82 Football School of Malang. 
Some of the suggestions as a result of this research work are as explained below:

\section{Suggestion of Utilization}

This developed product is a shooting and dribbling training model that can be used as a reference product in conducting an exercise program while taking into account the situation, age, skill level of the player, as well as the training tools and utilities used during the training.

\section{Suggestion of Dissemination}

Before disseminating this product to a broader target, the researcher proposes:

a. that the product should be rearranged to a better form which include its content, pictures and general package.

b. that it should be socialized to the football association around as a template in shooting and dribbling training.

\section{Suggestion of Development}

In developing the results of this research further, the researcher proposes:

a. that it should be done on a broader subject which can be based on age, number of subjects and the number of football associations used.

b. that its development be based on its effectiveness.

c. that the trials, analysis or the effectiveness level be compared with some form of training model seen as best or effective in improving shooting and dribbling in an individual or the subjects at Unibraw 82 Football School of Malang.

\section{ACKNOWLEDGMENT}

The researchers would like to express their profound gratitude to the Rector of IKIP Budi Utomo Malang for the motivation given to lecturers of IKIP Budi Utomo Malang to sustain the three pillars of higher education, and also to the Head and expert staff members of P2M of IKIP Budi Utomo Malang who coordinated and reviewed the research proposals of the lecturers of IKIP Budi Utomo Malang and led to the selection of my research proposal for a grant from the Minister of Research, Technology and Higher Education (Kemenristekdikti). And for getting this grant, the research must be improved upon and be published in an international research journal and textbook. In addition, my gratitude goes to the Universitas Negeri Yogyakarta (UNY) in organizing an International seminar conducted by the UNY School of Science Faculty committees where the researchers participated as presenters during the seminar at YISHPESS FIK UNY 2018.

\section{REFERENCES}

[1] Batty, Eric C. 2003. Latihan Sepakbola: Metode Baru Serangan. Bandung: Pioner.

[2] Gifford, Clive. 2003. Sepak Bola. Jakarta: Airlangga.

[3] Suharno. 1993. Metodologi Pelatihan. Jakarta: KONI Pusat

[4] Bompa, Tudor. 1987. Theory and Methodology of Trainning: The Key to Athletic.Performance. Toronto, Ontario Canada: Kendall/Hunt Publishing Company.

[5] Scheunemann, Timo. 2005. Dasar Sepak Bola Modern. Malang: Dioma.

[6] Sadiman, Arif S. 2003. Media Pendidikan: Pengertian, Pengembangan dan Pemanfaatannya. Jakarta: Pustekkom Dikbud.

[7] Arikunto, Suharsimi. 1998. Prosedur Penelitian, Edisi Revisi IV. Jakarta: PT Rineka Cipta.

[8] Syarifuddin, Aip 1996 Ilmu Kepelatihan Dasar. Jakarta: Depdikbud Dirjen Dikti Proyek Pendidikan Tenaga Akademik.

[9] Sucipto. 2000. Sepakbola Latihan dan Strategi. Jakarta: Jaya Putra.

[10] Mielke, Danny. 2003. Dasar Dasar Sepakbola. Bandung: Pakar Raya.

[11] Luxbacher, Joseph A. 1998. Sepak Bola. Jakarta: PT. Raja Grafindo Persada.Pate, R Russel, McClenaghan, Bruce \& Rotella, Robert. 1993. Dasar-Dasar Ilmiah Kepelatihan. Terjemahan Kasiyo Dwijowinoto. Semarang: IKIP Semarang Press.

[12] Dedeng, NY. 2002. Konsep Penelitian Pengembangan. Makalah disajikan dalam Lokakarya Nasional Angkatan II Metodologi Penelitian Pengembangan. Bidang Pendidikan dan Pembelajaran. Pusat Penelitian Pendidikan Lembaga Penelitian Jurusan Ilmu Keolahragaan Universitas Negeri Malang, Hotel Anda Batu, Malang, 2002, 22-24 Maret. 